\title{
Correction to: Contractions with rational inequalities in the extended $b$-metric space
}

Badr Alqahtani ${ }^{1}$, Andreea Fulga ${ }^{2}$, Erdal Karapınar ${ }^{3 *}$ and Vladimir Rakočević ${ }^{4}$

\author{
"Correspondence: \\ erdalkarapinar@yahoo.com; \\ karapinar@mail.cmuh.org.tw \\ ${ }^{3}$ Department of Medical Research, \\ China Medical University Hospital, \\ China Medical University, Taichung, \\ Taiwan \\ Full list of author information is \\ available at the end of the article
}

Correction to: J. Inequal. Appl. (2019) 2019: 220. https://doi.org/10.1186/s13660-019$2176-6$

The authors would like to express their sincere appreciation to the Deanship of Scientific Research at King Saud University for funding this group No. RG-1437-017. The corrected funding of the original article [1] is listed below.

\section{Funding}

Funding for the group was provided by the Deanship of Scientific Research at King Saud University, No. RG-1437-017.

\section{Author details}

'Department of Mathematics, King Saud University, Riyadh, Saudi Arabia. ${ }^{2}$ Department of Mathematics and Computer Sciences, Universitatea Transilvania Brasov, Brasov, Romania. ${ }^{3}$ Department of Medical Research, China Medical University Hospital, China Medical University, Taichung, Taiwan. ${ }^{4}$ Faculty of Sciences and Mathematics, University of Nišs, Niš, Serbia.

Published online: 29 August 2019

\section{References}

1. Alqahtani, B., Fulga, A., Karapınar, E., et al.: Contractions with rational inequalities in the extended $b$-metric space. J. Inequal. Appl. 2019, 220 (2019). https://doi.org/10.1186/s13660-019-2176-6

(c) The Author(s) 2019. This article is distributed under the terms of the Creative Commons Attribution 4.0 International License (http://creativecommons.org/licenses/by/4.0/), which permits unrestricted use, distribution, and reproduction in any medium, provided you give appropriate credit to the original author(s) and the source, provide a link to the Creative Commons license, and indicate if changes were made. 